\title{
Characterisation of camel breeding practices in the Ansongo Region, Mali
}

\author{
Bakary Traoré • Nassim Moula • Abdoulaye Toure • \\ Bara Ouologuem • Pascal Leroy • \\ Nicolas Antoine-Moussiaux
}

Accepted: 8 July 2014 / Published online: 26 July 2014

(C) Springer Science+Business Media Dordrecht 2014

\begin{abstract}
Despite its importance in Mali's economy, camel breeding in the country remains poorly documented, impeding effective policy-making in this regard. This study consisted in a 3-month survey and aimed at characterising camel breeding systems in Ansongo, in the region of Gao, Mali. It highlights the diversity of strategies adopted by breeders and their evolutions. Supplementary feeding and veterinary care were seldom practised. In zones close to the Niger River, cattle were substituted to camels. Transhumance routes also are modified but mobility keeps its vital role in the breeding system. Important differences within the study region in the classification of camel breeds have been reported that will influence the implementation of a collective action for animal genetic improvement. The improvement goals should take the actual management, including mobility and the mixed nature of the herds into account.
\end{abstract}

Keywords Breeding systems $\cdot$ Dromedary camel $\cdot$ Animal genetic resources $\cdot$ Ansongo $\cdot$ Mali

B. Traoré $\cdot$ N. Moula $\cdot$ A. Toure $\cdot$ P. Leroy $\cdot$ N. Antoine-Moussiaux Department of Animal Productions, Faculty of Veterinary Medicine, University of Liege, Boulevard de Colonster, 20, building B43, 4000 Liège, Belgium

B. Ouologuem

Institute of Rural Economics (IER), Bamako, Mali

N. Moula $\cdot$ P. Leroy $\cdot$ N. Antoine-Moussiaux $(\square)$

Tropical Veterinary Institute, Faculty of Veterinary Medicine,

University of Liege, Boulevard de Colonster, 20, building B43,

4000 Liège, Belgium

e-mail: nantoine@ulg.ac.be

\section{Introduction}

The characterisation of breeding systems and their diversity is key in the tailoring of effective policies for the development of the livestock sector. Camel breeding systems across the world have been studied and typologies defined in order to inform policy-making or improvement actions (Michel et al. 1997; Laval et al. 1998; Chaibou and Faye 2005; Bénard et al. 2008; Abdallah and Faye 2013). The typological approach aims at characterising the diversity of structures and practices across a livestock sector notably through multivariate analysis with defined practical goals. These goals influence the types of discriminant variables included in the initial analysis. As an illustration, the typological approach has been used recently in the European cattle production, based on the attitudes and objectives of the farmers, in the prospect of framing future policies regarding biodiversity management (Soini et al. 2012).

In Mali, despite its importance in the national economy, the dromedary has been neglected in development programs and few studies on camel breeding systems in the country are available. The main part of these poorly coordinated works has been led in the 1980s (Ouologuem et al. 2004). In 2000, due to environmental, economic and social upheavals, however, the political interest in camel breeding was renewed. Facing these upheavals, breeders are constantly adapting their practices. This adaptation consists in a change in the modes of feeding and watering, meaning a change in their mobility. Moreover, any evolution of the breeding systems implies an evolution in the management of animal genetic resources on which they are founded. Modifications thus affect the composition of the animal portfolio by species substitution, interbreeds substitution and breed reorientation (Homann et al. 2008). In order to understand the diversity of camel breeding strategies in Northern Mali and their implication for animal genetic resources, this study propose a characterisation of 
camel breeding systems and their evolution in Ansongo, in the Gao province, Mali.

\section{Material and methods}

Study area

The Ansongo district is located in the south of the Gao province $\left(15^{\circ}-17^{\circ}\right.$ north latitude, $0^{\circ}-1^{\circ}$ east longitude). The climate is semi-arid with a long dry season, from the end of September to June, and a highly variable rainy season, from July to September (200-300 mm/year). The Ansongo district $\left(23,614 \mathrm{~km}^{2}\right)$ is composed of seven communes, including 23 villages and 62 nomadic settlements. The area covers two climatic zones. The Hausa zone is desertic, subject to a hot and dry wind coming from the Sahara. The Gurma zone has a Sahelian climate, with favoured microclimatic areas near the Niger River. The Ansongo district has 131,953 inhabitants, comprising sedentary populations, mainly Sonrhaïs, and mobile populations: Fulanis, Tuaregs, Bellas, Daoushaqs and Arabs (National Institute of Statistic 2011). The livestock is estimated at 99,000 cattle, 325,000 small ruminants, 22,000 donkeys and 28,400 camels (Regional Direction of Veterinary Service of Gao 2008).

\section{Sampling}

From November 2010 to January 2011, a sample of 100 camel-keeping households was surveyed, i.e. 50 households in each climatic zone, Gurma and Hausa (Fig. 1). Two communes were included in each zone according to camel populations (official figures) and accessibility of the commune (security). In Gurma, the communes of Tessit and Wataguna, close to the river, were sampled. In Hausa, the communes of Tin-Hama and Talataye were selected, away from the river and subject to a more arid climate. In each commune, the areas with dense camel populations were identified with the village chiefs and the livestock services. At least three villages were purposively retained per commune, on the basis of camel population. The sampling of households inside the villages was achieved by transect walk. The local chief introduced the contact with the households but did not assist in the interviews.

\section{Interviews}

The interviews were of the structured type, including openended and close-ended questions. An interpreter speaking French and Tamasheq was present. The topics covered by the questionnaire were the socio-economic characteristics of the breeder, the strategy of mobility, the herd management practices (feeding, health, reproduction) and the camel breeds.
Statistical analysis

All statistical analyses were performed with the $\mathrm{R}$ software ( $\mathrm{R}$ 2.8.0).

The differences between Hausa and Gurma and between communes were tested through analysis of variance regarding quantitative variables and through chi-square test regarding qualitative variables. The Kruskal-Wallis test was used to compare animal numbers.

For the multivariate analysis, from 38 categorical and quantitative variables collected through the survey, 11 were finally selected according to the variability of the values observed in the sample, an a priori knowledge of the breeding system and the goal of the study. All quantitative variables were transformed into categorical variables by defining classes, considered as meaningful on the basis of qualitative information collected during the survey and the resulting repartition of the total sample. A multiple correspondence factorial analysis (MCA) was performed on the 11 variables with the R package FactoMineR (Lê et al. 2008). All variables with modalities showing insufficient contribution to the MCA axes (i.e. a contribution lower than weight) were left out of the final model. The final variables pertained to herds' structure (number of camels, presence of cattle, presence of sheep), mobility (duration per year, distance per year, share of herd moving, share of household moving, variability of the routes) and practices (feeding, health practices, hiring of labour) (Table 1). For axis interpretation, the relative contribution of variables was taken into account; coordinates of modalities with absolute values greater than the square root of axis eigenvalue were considered for interpretation. Hierarchical classification, using the algorithm of Ward (package FactoMineR, function HCPC), was then performed on the basis of the MCA results to formulate a typology. The commune and typology class were included in the analysis as supplementary qualitative variables to test the linkage of their modalities with the computed axes.

\section{Results}

Characteristics of the sampled breeders and herds

The sampled breeders were Tuaregs $(75 \%)$ or Daoushaqs (25\%). The average age was 33 years (minimum 30; maximum 42). Seventy-five percent had an Islamic education. Livestock was the principal activity of $95 \%$ of the interviewees. Other principal activities were teaching, political mandate or agriculture. The practice of a secondary activity was more frequent in the communes of Tessit and Tin-Hama (56 and $72 \%$, respectively) than in Talataye and Wataguna (20 


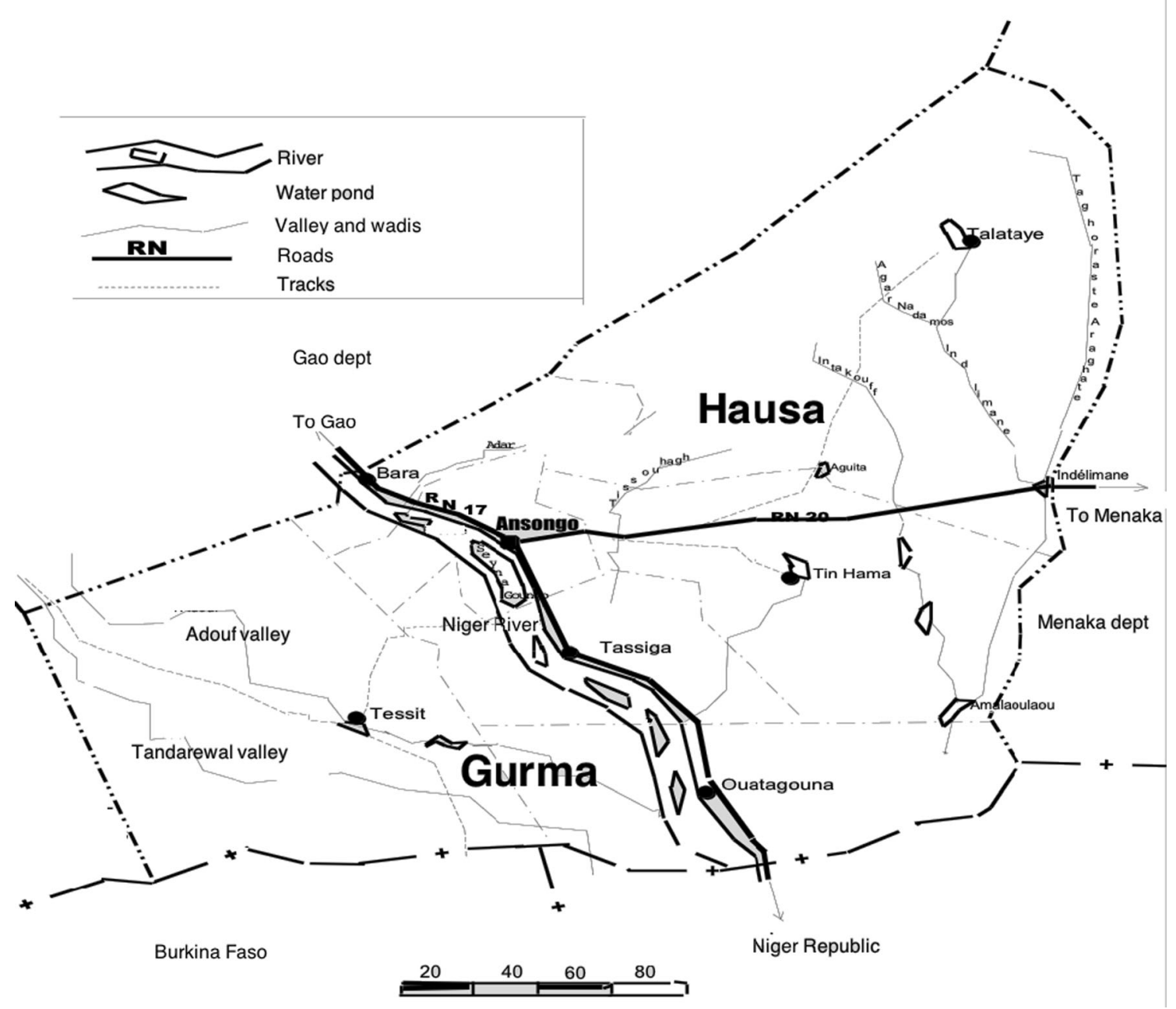

Fig. 1 Locational map of the study area

and $36 \%$, respectively) $(P<0.001)$. These secondary activities were commerce and subsistence agriculture.

Besides camels, the sampled herds included cattle, small ruminants and donkeys (Table 2). Goats were found in all herds. Sixty-four percent of the interviewees owned sheep and $51 \%$ owned cattle. The total number of camels in the 100 herds amounted to 3,101 heads. The herd size was slightly but significantly higher in Hausa compared to Gurma, with median sizes of 32 and 26 heads, respectively $(P<0.05)$. Among the 18 herds over 40 camels, 16 were in Hausa. The median number of cattle was higher in Tessit $(P<0.05)$.

\section{General description of practices}

\section{Mobility}

In the study area, camel herds were mobile all year long, with total distances between 10 and $500 \mathrm{~km}$ and total mobility duration from 2 to 4 months. Mobility is mainly a strategy for access to pastures and water. Other cited motives for mobility were the cure salée ( $25 \%$ ) and avoiding the conflicts with farmers $(15 \%)$. The latter motive was more particularly cited in Tessit and Tin-Hama ( 9 and $6 \%$, respectively). In $53 \%$ of cases, only young members of the household participated to herd movements. In $27 \%$ of herds, external labour was hired to drive the herd.

\section{Valorisation of camel products}

The stated individual milk production varied from 2 to 61 per day. Most camel owners (92\%) did not sell their camel milk and are not willing to do so for cultural reasons. Only $8 \%$ state their willingness to sell milk in case of abundance. No fattening was practised prior to the sale of camels. Only emergency sale was practised in case of financial need. The number of camels sold or slaughtered per year was $10.27 \pm 4.96 \%$ of total herd or about one animal sold yearly per eight adult females owned. The price per camel varied from 150 to 300,000 FCFA. The camels sold were adult males for $75 \%$ of them, adult females in $15 \%$ of cases and calves in $10 \%$. In all 
Table 1 Variables included in the multivariate analysis and herds' number by modality and commune
Tes. Tessit, Wat. Wataguna, Tal. Talataye, Tin Tin-Hama, Stat statistical significance of the chisquare or exact Fisher's test for differences between communes, $n s$ not significant

$* p<0.05 ; * * p<0.01 ;$ $* * * p<0.001$

\begin{tabular}{|c|c|c|c|c|c|c|c|}
\hline \multirow[t]{2}{*}{ Variable } & \multirow[t]{2}{*}{ Modalities } & \multirow[t]{2}{*}{ Percent } & \multicolumn{4}{|c|}{ Number per commune } & \multirow[t]{2}{*}{ Stat } \\
\hline & & & Tes. & Wat. & Tal. & Tin & \\
\hline \multirow[t]{3}{*}{ Yearly duration of herd movements } & 2 months & 32 & 6 & 13 & 0 & 13 & \multirow[t]{3}{*}{$* * *$} \\
\hline & 3 months & 34 & 10 & 8 & 4 & 12 & \\
\hline & 4 months & 34 & 9 & 4 & 21 & 0 & \\
\hline \multirow[t]{4}{*}{ Maximal distance } & Under $50 \mathrm{~km}$ & 23 & 6 & 9 & 0 & 8 & \multirow[t]{4}{*}{$* * *$} \\
\hline & 51 to $100 \mathrm{~km}$ & 36 & 15 & 12 & 3 & 6 & \\
\hline & 101 to $200 \mathrm{~km}$ & 18 & 4 & 4 & 5 & 5 & \\
\hline & Over 200 km & 23 & 0 & 0 & 17 & 6 & \\
\hline \multirow[t]{2}{*}{ Herd share moving } & Total herd & 50 & 8 & 8 & 22 & 12 & \multirow[t]{2}{*}{$* * *$} \\
\hline & Partial & 50 & 17 & 17 & 3 & 13 & \\
\hline \multirow[t]{3}{*}{ Household members accompanying herd } & None & 11 & 0 & 9 & 2 & 0 & \multirow[t]{3}{*}{$* * *$} \\
\hline & Young members & 53 & 21 & 12 & 2 & 18 & \\
\hline & All & 36 & 4 & 4 & 21 & 7 & \\
\hline \multirow[t]{2}{*}{ Routes } & Fixed & 30 & 6 & 7 & 11 & 6 & \multirow[t]{2}{*}{ ns } \\
\hline & Variable & 70 & 19 & 18 & 14 & 19 & \\
\hline \multirow[t]{2}{*}{ Crop residues use } & Yes & 21 & 12 & 2 & 0 & 7 & \multirow[t]{2}{*}{$* * *$} \\
\hline & No & 79 & 13 & 23 & 25 & 18 & \\
\hline \multirow[t]{2}{*}{ Health practices } & Yes & 30 & 3 & 6 & 9 & 12 & \multirow[t]{2}{*}{$*$} \\
\hline & None & 70 & 22 & 19 & 16 & 13 & \\
\hline \multirow[t]{3}{*}{ Number of camels } & Under 20 & 21 & 9 & 8 & 3 & 1 & \multirow[t]{3}{*}{$*$} \\
\hline & 21 to 40 & 61 & 15 & 16 & 16 & 14 & \\
\hline & Over 40 & 18 & 1 & 1 & 6 & 10 & \\
\hline \multirow[t]{2}{*}{ Herd includes cattle } & Yes & 60 & 22 & 13 & 13 & 12 & \multirow[t]{2}{*}{$*$} \\
\hline & No & 40 & 3 & 12 & 12 & 13 & \\
\hline \multirow[t]{2}{*}{ Herd includes sheep } & Yes & 68 & 18 & 19 & 13 & 18 & \multirow[t]{2}{*}{$\mathrm{ns}$} \\
\hline & No & 32 & 7 & 6 & 12 & 7 & \\
\hline \multirow[t]{2}{*}{ Hired herder } & Yes & 30 & 11 & 15 & 2 & 2 & \multirow[t]{2}{*}{$* * *$} \\
\hline & No & 70 & 14 & 10 & 23 & 23 & \\
\hline
\end{tabular}

households, the main production of camels was labour, but its use for ploughing was only found in $10 \%$ of households.

\section{Feeding and watering}

Feeding was based on natural pastures. Only $18 \%$ of herds received occasional supplementation with cotton oilcakes. Crop residues were used by $13 \%$ of breeders. The supplemented animals were lactating she-camels and diseased animals. Salt supplementation of the whole herd was practised regularly by $95 \%$ of breeders. This practice was presented as a second-best, lacking an access to salty lands (cure salée).

Collective or private wells were the main source for watering (90\%). Temporary water holes were exploited in $85 \%$ of herds. The Niger River was mainly used in Gurma and exceptionally by breeders from Hausa, in case of severe drought. The majority of breeders in Gurma watered their herd thrice a week vs. twice in Hausa. Water lifting was mostly done with camels or donkeys.

Table 2 Herd composition by communes presented as median (min-max)

\begin{tabular}{|c|c|c|c|c|c|}
\hline Communes & Tessit & Watagouna & Talataye & Tin-Hama & Stat. \\
\hline Camel & $23(12-69)$ & $23(10-40)$ & $34(16-54)$ & $34(19-81)$ & $*$ \\
\hline Cattle & $14(1-35)$ & $7(1-17)$ & $5(1-15)$ & $5.5(2-15)$ & ns \\
\hline Sheep & $5.5(1-16)$ & $5(1-23)$ & $8(1-15)$ & $5(1-11)$ & ns \\
\hline Goat & $13.5(2-25)$ & $15(2-25)$ & $15.5(2-35)$ & $18(1-37)$ & ns \\
\hline Donkey & $3.5(3-4)$ & $2(1-3)$ & $1(1-2)$ & $2(1-4)$ & ns \\
\hline
\end{tabular}

Stat. statistical significance of the Kruskal-Wallis test for difference in numbers between communes, $n s$ not significant $\left.{ }^{*} p<0.05 ; * * p<0.01 ; * * * p<0.001\right)$ 
Seventy-five percent of breeders mentioned intoxication problems in camels when led in new pastures during herd movements. The clinical signs were bloating, neck wrecking, abortions, shivering and sudden death. Four incriminated plants were identified: ewane (Feretia apodanthera), tarakate (Ziziphus mucronata), agarof (Tribulus terrestris) and tanela (Ipomoea asarifolia).

\section{Health}

The most cited syndromes in camels could be divided in general affections $(84 \%)$, respiratory $(68 \%)$, gastrointestinal (50\%), locomotor (45\%), nervous (33\%) and skin diseases $(32 \%)$. The local names used for the reported syndromes are detailed in Table 3.

Over $95 \%$ of breeders had recourse to ethno-veterinary medicine. According to breeders, livestock and veterinary services targeted cattle and small ruminants and neglected camels. Regarding modern veterinary medicine, $70 \%$ of breeders did use neither anthelmintics nor vaccination for their camels. Twelve percent of camel herds were vaccinated, being all located in Hausa.

\section{Reproduction}

Herds were mainly composed of adult females (76.89 \pm $7.31 \%$ ). The female-to-male ratio in adults was about 7 (Table 4). The mean stated age at first calving in females and age at first mating in males were lowest in Tin-Hama and highest in Wataguna (Table 4). Weaning was practised in $30 \%$ of herds in Hausa vs. $15 \%$ in Gurma. The age at weaning varied from 10 to 15 months. The calving period was reported to take place from July to January for all herders in Talataye and Tessit, for $88 \%$ of them in Tin-Hama and $12 \%$ in Wataguna.

In $61 \%$ of herds, castrated males were sold on the livestock markets. Castrated males were also kept for the lifting of water and transport. Sixty-five percent of herders selected the potential breeders among 2- to 3-year-old males. The most cited criteria for selection were milk production of the mother (25\%), beauty (25.5\%), resistance (18.5\%), colour (19\%) and speed (12\%) (Table 5). The sated breeding life varied from 10 to 23 years.

\section{Cluster analysis of practices}

The first three MCA dimensions accounted for $40.3 \%$ of sample variation. The variables showing the highest relative contribution to dimension 1 were those characterising mobility, i.e. family share accompanying herd movement (24.2\%), distance (21.5\%), herd share moving (17.7\%) and duration $(15.3 \%)$. Variables contributing the most to dimension 2 were herd size $(33.0 \%)$, health practices $(18.8 \%)$ and family share accompanying herd movement (17.2\%). Variables contributing the most to dimension 3 were duration $(37.2 \%)$, route variability (14.5\%) and owning of cattle (11.9\%).

Along dimension 1, the modalities typical for highly mobile herds showed negative coordinates, i.e. 4 months and over $200 \mathrm{~km}$ of yearly movement $(-0.98$ and -1.45 , respectively), with the whole herd moving $(-0.78)$ and the whole household accompanying (-1.21). Dimension 2 opposed small camel herds' modality (below 20 heads; coordinate -0.62 ) to large herds' modality (over 40 heads; coordinate 1.49). The use of veterinary treatments showed a positive coordinate $(0.83)$ on axis 2 , while the lack of household members accompanying the herd movement showed a negative coordinate $(-1.36)$. Dimension 3 was negatively associated to the modality 3 months movement per year (coordinate $-0.92)$ and to the modality of constant routes $(-0.70)$. It was positively associated to large camel herd $(0.81)$ and the absence of cows in the herd (0.51).

The hierarchical classification of individuals led to the description of four clusters (conserving $67.5 \%$ of variability between clusters). As shown by chi-square test, clusters showed highly significant dependence to household share moving, movement duration and distance, commune, camel herd size, herd share moving, and the hiring of labour $(P<0.0001)$, and very significant dependence to variability of routes, and owning of cattle $(P<0.001)$, and significant dependence to the use of supplementary feed and veterinary treatments, and the owning of sheep $(P<0.05)$.

Table 3 Main syndromes as described by breeders

\begin{tabular}{llll}
\hline Tamasheq name & Principal signs & Particularity & Treatments \\
\hline $\begin{array}{l}\text { Achni wakkoussane } \\
\text { Achni wassamidane }\end{array}$ & $\begin{array}{l}\text { Sudden death } \\
\text { Cachexia }\end{array}$ & Ascribed to an excess of blood & Bleeding at jugular vein \\
Achiyed & Itching, alopecia & Mainly in dry hot season, contagious & Motor oil, animal fat \\
Taminike & Saddle and harness sore & Followed by infection and myiasis & Tobacco decoction, motor oil \\
Tagourmalt & Ticks infestation & Rainy season & Insecticides \\
Toza or anafad & Nasal discharge, cough, dyspnea & Cold and dry season & Tobacco in nostrils, running \\
& & & facing the wind
\end{tabular}


Table 4 Breeding management in the four surveyed communes (LSMeans \pm SE)

\begin{tabular}{lrrrr}
\hline & Tessit & Ouatagouna & Talataye & Tin-Hama \\
\hline Female to male ratio & $8.34 \pm 7.25 \mathrm{a}$ & $6.99 \pm 6.67 \mathrm{a}$ & $6.43 \pm 6.50 \mathrm{a}$ & $8.08 \pm 7.50 \mathrm{a}$ \\
Age at first calving & $6.00 \pm 0.23 \mathrm{a}$ & $6.36 \pm 0.23 \mathrm{a}$ & $6.12 \pm 0.23 \mathrm{a}$ & $5.16 \pm 0.23 \mathrm{~b}$ \\
Age at first mating for males $^{\text {Age at weaning }}{ }^{\mathrm{a}}$ & $7.16 \pm 0.21 \mathrm{a}$ & $7.40 \pm 0.21 \mathrm{a}$ & $7.08 \pm 0.21 \mathrm{a}$ & $5.64 \pm 0.21 \mathrm{~b}$ \\
\hline
\end{tabular}

Different lowercase letters following values indicate statistically significant difference between values on a same line

${ }^{a}$ Forty-five households practised weaning among the 100 surveyed (Tessit 10, Wataguna 5, Talataye 13, Tin-Hama 17)

The first cluster may be characterised as one of pure nomadism. It includes 34 breeders, 33 of which move yearly with the whole herds and household (97.1\%). In this cluster, herd sizes were comprised between 21 and 40 camels (76.5\%) and movements extended on 4 months per year $(76.5 \%)$. They did not hire labour $(100 \%)$ and did not use feed supplements $(97.1 \%) ; 61.8 \%$ of them were located in Talataye commune and $61.8 \%$ also did not have cattle. The second cluster may be characterised as one of long transhumance. It includes 28 herds with camel numbers under 40 heads $(100 \%)$. They are characterised by medium distances (78.6\% between 51 and $100 \mathrm{~km}$ yearly) and variable routes $(96.4 \%)$. Ninety percent of breeders not accompanying herd movement are in this cluster, as well as $53.3 \%$ of those hiring labour. Half of them are located in the Wataguna commune. The third cluster may be characterised as one short transhumance. It includes 12 herds, most of which include more than 40 camels, move for 2 months per year, letting the young members of the household accompany the herd, and are located in the Tin-Hama commune $(91.7 \%$ for each modality); $83.3 \%$ of them follow variable routes. Two thirds of them use veterinary treatments. The fourth cluster may be characterised as one transhumance with split herd. It includes 26 , among which $92.3 \%$ move only with the nonproductive herd, letting the young members of the household lead the herd. Most of them own cattle and sheep $(88.5 \%$ for both species); $61.5 \%$ follow fixed routes. Almost half of them (46.1\%) are located in Tessit.

Table 5 Citation rates of the main selection criteria for breeding males (\%)

\begin{tabular}{llllll}
\hline Criteria & \multicolumn{2}{l}{ Commune } & & \multirow{2}{*}{ Total } \\
\cline { 2 - 5 } & Tessit & Wataguna & Talataye & Tin-Hama & \\
\hline Beauty & 29 & 27 & 21 & 25 & 25.5 \\
$\begin{array}{l}\text { Mothers' milk } \\
\text { production }\end{array}$ & 22.5 & 25 & 27 & 25.5 & 25 \\
$\begin{array}{l}\text { Colour } \\
\text { Resistance }\end{array}$ & 23 & 21 & 15 & 17 & 19 \\
Speed & 12 & 16 & 21 & 25 & 18.5 \\
\hline
\end{tabular}

Animal genetic resources and camel breeds

The ways herders classify the types of camels differ between Gurma and Hausa. In Hausa, two types are distinguished, the Tilabayaten and the Talmorokit, on the basis of the overall conformation, production ability (milk, speed, draught) and colour. The Tilabayaten is described as white or light grey; it is high at withers with a slender silhouette. Its milk production is reported to be higher than that of the Talmorokit. The latter type is dun and smaller. Its heavier conformation makes it suitable for the transport of goods.

In Gurma, nine types are described. Seven are distinguished and named after their colour, including the Azargaf that is characterised by its piebald colour and blue eyes. The two remaining types are the Adignas, which means 'trustable animal', and the Awinag, which is characterised by its totally white colour and a vision defect.

\section{Discussion}

Typology of breeding practices: overview

The strategy of mobility proved an important feature in the MCA and constitution of clusters. Herd size and commune also proved discriminant between clusters. Herd composition, feeding or health management were less strongly associated to MCA but proved nevertheless important in the understanding of the evolution of the system, as detailed below. The link between clusters and communes highlights the geographic variability of production systems, tied to environmental and historical factors, as explained hereunder.

The typical nomadism, corresponding to clusters 1 and 3 , was more present in Hausa (Talataye and Tin-Hama). Cluster 3 differed from cluster 1 by the use of veterinary treatment, the duration of movement and the share of household accompanying herd. It can be considered as a nomadic system in transition to transhumance. Characterised by the hiring of labour and the sedentarisation of household members, livestock in cluster 2 appears as capital investment, although 
breeders keep involved in management decision. In Gurma, and particularly Tessit, the greater presence of cattle and the use of crop residues show a trend to intensification. This corresponds to cluster 4 , where some form of integration between livestock and crops is observed. However, the use of veterinary treatments did not follow in this trend and proved unexpectedly more frequent in the nomadic herds of cluster 3 (Tin-Hama).

\section{Practices}

\section{Herd composition}

Facing a variable environment, camel herders adapt their mobility and herd composition, as a portfolio, species contributing uniquely to household's livelihoods and resilience (Lhoste 2007). In Tessit, as figured by cluster 4, a substitution of cattle for camel was highlighted in household histories. The willingness to sedentarise near the riverbanks, the poor adaptation of camel to this humid environment and the slow reproductive cycle of camel are the main stated motives for that trend. Therefore, sedentarisation and the search for rapid profitability diminish the importance of camels as a tool for drought risk management. Homann et al. (2008) describe an inverse situation in Ethiopia, where sufficiently endowed household, facing environmental and socio-political uncertainty, opt for mobility and invest in camels and small ruminants to increase and secure their production. A strategy of sedentarisation and adoption of small-framed cattle is also observed in other groups by these authors, but is interpreted as a sign of distress in less-endowed households. Across the Sub-Saharan 'desert-bell', the adoption of camel and small ruminants is also reported as a response to environmental and economical challenges, being also part of sedentarisation strategies (Faye et al. 2012). Therefore, sedentarisation cannot be considered as automatically associated to a neglect of camels. Also that neglect by some breeders in the present study might be a result of restricted investment (and risk-taking) ability and a weak development of market for camel products.

\section{Mobility}

In Talataye (cluster 1), the whole household accompanied the herd movements, thus corresponding to nomadism as defined by Retaillé (2003). In Tessit and Wataguna (clusters 2 and 4), the herd movements were of transhumant nature, i.e. seasonal movements of herds accompanied by the herder and part of the household, along determined routes from and to a fixed main camp (Saidu 1986). The insecurity in the region entails a trend towards the shortening of distances. On the longer run, pure nomadism may disappear from the region. Such generalised shift of nomadic populations towards transhumant strategies may occur at the expense of an optimal exploitation of semi-arid lands and lead to the overexploitation of favoured areas.

Breeders commonly explained that mobility is fundamental to the camel physiology, whatever the availability of fodder and water. Therefore, sedentarisation of camel breeding appears to them as unrealistic. A strong motive for mobility was also the reinforcement of social cohesion with other tribes or nomadic groups. Together with the practice of commerce, these motives show that mobility is deeply rooted in a lifestyle and culture, which is important to acknowledge in livestock development programs.

\section{Valorisation of camel products}

In the present systems, the financial role of animals is crucial: while small ruminants represent easily mobilisable savings, camels and cattle are longer-term savings, for exceptional needs. The market demand nevertheless influenced the destocking decision for camels. Indeed, camel-calves or adult females may be sold when price is favourable.

The present cultural reluctance to sell camel milk was justified by breeders as a component of traditional solidarity networks. In Western Sahara, such reluctance was also observed but governmental efforts could spur the development of a value chain for camel milk (Faye 2003). Indeed, this cultural reluctance is tied to the present production levels and the lack of outlets, thus the lack of permanent incentive to sell milk. Therefore, a joint support to camel breeders and to the development of camel milk markets in Ansongo should contribute by itself to the needed change in habits regarding camel milk marketing.

\section{Feeding}

The use of supplement feed was uncommon (except for salt), particularly in Talataye (cluster 1). From March to July, fodder is scarce and of poor quality. In these extreme conditions, even the moderate feed complementation practices observed in some herds are highly beneficial to camels' health and production. In agricultural zones (Gurma), crop residues are used for feeding along with a diversification of pastures, as in the case of clusters 2 and 4 . The use of cotton oilcake was very limited in Ansongo region, due to poor physical and financial access to those. Nevertheless, its use in Tin-Hama (cluster 3) was observed, probably ensuing from an extension project held in 2004. This indicates that while access to oilcakes is poor, this practice met a sustained success due to its visible benefits. However, it could not be adopted in a wider area and kept restricted to the project area. In general, complementary feeding in camel production is motivated by the availability of outlets for camel milk or work (Chaibou and Faye 2005). Therefore, in Ansongo, where herders proved prone to adopt 
complementary feeding, a support of milk marketing and access to oilcakes or other complements should be successful.

\section{Health}

The public and private veterinary structures in the study region are weak. Van Den Bossche et al. (2004) described the complex socio-economic mechanisms impairing the development of veterinary services in rural zones of Africa. Private veterinarians are poorly equipped and unwilling to work in remote camel-rearing areas. Public services are also weakly engaged in camel production and herders mainly rely on ethno-veterinary practices. The remoteness of the camelrearing areas makes it a common feature across the world; e.g. in Pakistan, Aujla et al. (1998) indicated that $70 \%$ of herders had recourse to those practices. Thus, breeders have developed a fine understanding of herd health management; they are able to recognise and categorise diseases according to their own nomenclature that may correspond quite closely to western medical categories (Antoine-Moussiaux et al. 2005). The treatments are diversified, using plants or more modern product, as motor oil (Antoine-Moussiaux et al. 2005, 2007; Raziq et al. 2010). While parasitic infestations are a major issue in camel production, only a minority of herds made here use of anthelmintics. Giving access to such treatments should raise high benefits, with an expected increase in milk production over $65 \%$ (Faye 2003).

\section{Reproduction}

The interviewed camel owners have a good expertise in breeding. The need to accompany unexperimented males during the coitus and the number of females per male are well-mastered practices. The earlier stated age at first mating in males and first calving in females in Tin-Hama should be confirmed by an individual follow-up, which is nevertheless not feasible in these difficult security conditions. If confirmed, this difference might be linked to the former extension efforts in the commune. The correlation between nutritional status and reproductive performance is indeed well known (Kaufmann 2005).

Weaning was a quite common practice in the present sample, at the average age of 13 months, close to that reported in Kenya (Mukasa-Mugerwa 1985). On the contrary, Chaibou and Faye (2005) indicated that weaning was not an active management practice in Agadez region, Niger.

The reported abortion rate around $35 \%$ is close to that cited by Ouologuem et al. (2004) in the same region. The breeders ascribed many of abortion cases to intoxication by ingestion of urticating caterpillars living on acacias. While this aetiology has not been scientifically established, it is a very common belief in the region of Sahel (Mali, Mauritania and
Niger) (Antoine-Moussiaux et al. 2005; Volpato et al. 2013).

Breeding males were seldom chosen outside the herd. Together with the low frequency of renewal of the breeding male, this practice entails consanguinity and possible negative effects on reproductive performances. Whether this practice is due to a lack of knowledge or to other practical constraints should be known in order to propose solutions. Castration aimed at discarding unwanted breeding males and at making males more docile for working purposes. The selection criteria for males were the aspect of the animal (colour, conformation), the performances (milk production of the mother, speed) and its adaptation to the harsh breeding conditions. Those were clearly stated by breeders, and the inclusion of ascendant performances in the criteria indicates a true expertise in this regard and an expected openness to modern selective breeding approaches. However, the low citation rates for all criteria tend to show a low agreement between breeders, which should be taken into account if collective action is to promote.

\section{Camel genetic resources}

At present, no definite inventory of camel breeds or types in Mali is available. The types cited in Hausa in the present survey are all included in the list of 12 types reported by Ouologuem et al. (2004). The Abzaw and Azargaf types might correspond to the Abzin and Azaghaf types described by Chaibou (2005) in Niger. This proposition is based on the similarity in the name used as well as of the respective colours of these types.

The difference in the mode of categorisation of camel types in the two ecological zones is an important result of the present survey. Indeed, programs for genetic improvement or for the management of genetic diversity need the full participation of breeders' communities. Therefore, a good knowledge of their classification modes and of the names they use is crucial in guiding the inventory and building of a fruitful communication. The unique classifications in close areas may be a constraint in the development of a collective action at the regional level, hence the importance of communication between different groups of beneficiaries at the early stage of a program.

The question of breed classification encompasses two distinct goals and thus approaches. A first approach refers to the genetic distance between populations, being useful in the decision-making regarding resource allocation for the conservation of biodiversity (Simianer 2005). According to that view, different names may refer to a same population, to manage as such. In Kenya, Mburu et al. (2003) proposed on the basis of molecular analyses that the camel types called Turkana, Gabbra and Rendille, defined on an ethno-sociologic basis, constitute one single genetic group, contrary to a fourth type recognised as unique, the Somali type. A second 
approach may acknowledge as breed any population considered as such by breeders. This vision is complementary to the first one. It aims at integrating other dimensions of genetic diversity, namely cultural aspects, indigenous knowledge, lifestyle and objectives of the breeders, in order to promote the appropriation of programs for the management of genetic diversity. Considering both approaches in the setting-up of national inventory programs could help avoid the pitfall of a confused accumulation of diverse denominations without any link to true genetic distances, while not restricting the question of biodiversity to that of a statistical distance between populations disregarding the systems that harbour them.

\section{Conclusion}

The present typology highlighted the geographic variability of production systems in Ansongo region, linked to environmental and historical factors. However, the link between geography and clustering proved imperfect, showing the need to take other basic criteria into account, among which herd size might be a simple one that proved determinant in the MCA and clustering process. As a first approach of camel production in a region with difficult access, this descriptive typological study should constitute a practical tool in the tailoring of livestock development policies, taking the importance of animal genetic resources into account. Clearly, the management, support or reorientation of mobility will be the main challenge of such policies. Hence, while different ecological zones need distinct developing approaches, this study also highlights common features, as the need to support camel milk marketing. A harmonisation in the classification of camel genetic resources in the whole region is also proposed as a useful step towards its management and improvement.

Conflict of interest The authors declare that they have no conflict of interest.

\section{References}

Abdallah, H. R., Faye, B., 2013. Typology of camel farming system in Saudi Arabia. Emirate, Journal Food Agricultural, 25, 250-260.

Antoine-Moussiaux, N., Faye, B., Vias, G., 2005. Tuareg ethnodiagnostic skill of camel diseases in Agadez area (Niger), Journal of Camel Practice and Research, 12, 85-93.

Antoine-Moussiaux, N., Faye, B., Vias, G., 2007. Tuareg ethnoveterinary treatments of camel diseases in Agadez area (Niger), Tropical Animal Health Production, 39, 83-89.

Aujla, K.M., Jasra, A.W., Munir, M., 1998. Socio-economic Profile of Camel Herders in South-Western Mountainous Areas of Pakistan. Proceedings of the third Animal Production under Arid Conditions, vol. 2, 154-174.
Bénard, C., Faye, B., Moulin, C.H., Kölher-Rollefson, I., 2008. A typology of the camel keepers in the Jaisalmer district, Rajasthan, India, Journal of Camel Practice and Research, 15, 231-238.

Chaibou, M., 2005. Productivité zootechnique du désert: le cas du bassin laitier d'Agadez au Niger (Thèse de doctorat). Montpellier II France, 310p. http://camelides.cirad.fr/fr/ science/pdf/these_chaibou.pdf

Chaibou, M., Faye, B., 2005. Fonctionnement des élevages camelins de la zone périurbaine de d'Agadez au Niger: enquête typologique, Revue d'élevage et de médecine vétérinaire des pays tropicaux, 4, 273-283.

Faye, B., 2003. Performances et productivités laitières de la chamelle: les données de la littérature. Séminaire international sur le lait de chamelle, Niamey, Niger, 4-6 novembre 2003. FAO-CIRADONG Karkara. $12 \mathrm{p}$.

Faye, B., Chaibou, M., Vias, G., 2012. Integrated impact of climate change and socioeconomic development on the evolution of camel farming systems. British Journal Environement Climat Change, 2, $227-244$.

Homann, S., Rischkowsky, B., Steinbach, J., Kirk, M., Mathias, E., 2008. Towards Endogenous Livestock Development: Borana Pastoralists' Responses to Environmental and Institutional Changes, Human Ecology, 36, 503-520 .

Kaufmann, B. A., 2005. Reproductive performance of camels (Camelus dromedarius) under pastoral management and its influence on herd development, Livestock Production Science, 92, 17-29.

Laval, G., Khanna, N.D., Faye, B., 1998. A typology of camel farming systems in Rajasthan. Revue Elevage Médecine Vétérinaire en Pays Tropicaux, 51, 147-152.

Lê, S., Josse, J., Husson, F., 2008. FactoMineR: An R Package for Multivariate Analysis. Journal of Statistical Software, 25 (1), url : http://www.jstatsoft.org/v25/i01

Lhoste, P., 2007. Sociétés pastorales et désertification au Sahel, Bois et forêts des tropiques, 293, 49-59. http://bft.cirad.fr/cd/BFT_293_4959.pdf

Mburu, D.N., Ochieng, J.W., Jianlin, H., Kaufmann, B., Reger, O., 2003. Genetic Diversity of Indigenious Kenyan Camel Populations; Implication for their Classification, Animal Genetics, 34, 26-32.

Michel, J.F., Bengoumi, M., Bonnet, P., Hidane, K., Zro, K,, Faye, B., 1997. Typologie des systèmes de production camélins dans la province de Laâyoune -Maroc. Revue Elevage Médecine Vétérinaire en Pays Tropicaux, 50, 313-323.

Mukasa-Mugerwa, E., 1985. Le chameau (Camelus dromaderius): Etude Bibliographique. CIPEA, Monographie 5, 111 p.

National Institute of Statistic, 2011. $4{ }^{\text {eme }}$ Recensement Général de la Population et de l'Habitat du Mali (RGPH): Résultats Définitifs. Bureau Central du Recensement - BCR BP, 12 - Bamako (Mali), Novembre 2011

Ouologuem, B., Moussa, M., Coulibaly, M.D., N'Diaye, M., 2004. Etude et amélioration du système d'élevage camelin, Rapport final de recherche, $10^{\mathrm{e}}$ session Comité de Programme, IER, $45 \mathrm{p}$.

Raziq, A., Verdier, K.D., Younas, M., 2010. Ethno veterinary treatments by dromedarius camel herders in the Suleiman Mountainous Regions in Pakistan: an observation and questionnaire study, Journal of Ethnobiology and Ethnomedicine, 6-16.

Regional Direction of Veterinary Service of Gao, 2008. Rapport annuel d'activités.

Retaillé, D., 2003. Le destin du pastoralisme nomade en Afrique. In: L'information géographique. 67-1-88-102. http://www.persee.fr/ web/revues/home/prescript/article/ingeo_0020-0093_2003_hos 6712857

Saidu, A., 1986. Contribution à l'étude d'un système pastoral sahélien: la transhumance au Niger: ses aspects, son incidence et les perspectives d'avenir. Thèse Doctorat Vétérinaire, Université de Dakar, Sénégal, 120p. 
Simianer, H., 2005. Decision making in livestock conservation, Ecological Economics, 53, 559-572.

Soini, K., Diaz, C., Gandini, G., De Haas, Y., Lilja, T., Martin-Collado, D., Pizzi, F., Hiemstra, S.J., Developing a typology for local cattle breed farmers in Europe. Journal of Animal Breeding and Genetics, 2012, 129, 436- 47.

Van Den Bossche, P., Thys, E., Elyn, R., Marcotty, T., Geerts, S., 2004. The provision of animal health care to smallholders in Africa: an analytical approach, Revue Scientifique et Technique de 1'OIE, 23, 851-861.

Volpato, G., Di Nardo, A., Rossi D., Lamin Saleh, S.M., Boglia, A., 2013. "Everybody knows", but the rest of world: the case of caterpillar-borne reproductive loss syndrome in dromedary camels observed by Sahrawi pastoralists of Western Sahara. Journal of Ethnobiology and Ethnomedicine, 9-5. 